\title{
ANTIOXIDANT ACTIVITY OF HYDRO-ALCOHOLIC EXTRACT ON THE ROOTS OF NYCTANTHES ARBORTRISTIS
}

\author{
SUMIT DAS, SHILPA PAUL, AKM ABDULLAH, ABDUL SAMIM \\ Girijananda Chowdhury Institute of Pharmaceutical Science, Azara, Hatkhowapara, Guwahati 17 \\ Email: shilpanita875@gmail.com
}

Received: 23 Apr 2018, Revised and Accepted: 10 Jun 2018

\begin{abstract}
Objective: To determine the antioxidant activity of Nyctanthes arbortristis (Family-Oleaceae).

Methods: The hydroalcoholic extract of the root of plant Nyctanthes arbortristis was taken into considerations to determine the phytochemicals present in it. The extracts of the roots were evaluated for antioxidant activity by using different in vitro model like Reducing Power Method and DPPH method.
\end{abstract}

Results: In the current investigation it has been found that the Pet. Ether and Hydroalcoholic extracts showed potent antioxidant activity by reducing power, as the concentration of the extracts increased, the absorbance was also increased correspondingly.

Conclusion: The hydroalcoholic extracts of this plant showed potent antioxidant activity against the standard drug (Kaempferol).

Keywords: Nyctanthes arbortristis, Phytochemistry, Antioxidant Activity

(C) 2018 The Authors. Published by Innovare Academic Sciences Pvt Ltd. This is an open access article under the CC BY license (http://creativecommons.org/licenses/by/4.0/) DOI: http://dx.doi.org/10.22159/ijcpr.2018v10i4.28463

\section{INTRODUCTION}

Free radicals are generally highly reactive and unstable compounds that can generate in the body during normal metabolic functions or it can form in the body from the external environmental sources such as environmental pollution and cigarette smoking. Antioxidants are the substances that can protect human bodies from oxidative damage of free radicals [1]. To balance the oxidative state, plants and animals maintain a complex system of overlapping antioxidants such as glutathione and enzymes (e. g. Catalase and superoxide dismutase) produced internally or the dietary antioxidants like vitamin $A$, vitamin $C$ (ascorbic acid), $\beta$-carotene and $\alpha$-tocopherol (a synthetic vitamin E) etc. Excessive production of free radicals can cause severe damage of cells and these may lead to various chronic diseases like cancer, stroke, heart disease, diabetes etc. Vitamins containing antioxidant are also helpful for the improvement of immune system functions [2] Now a day's lot of researches is going on to establish the therapeutic efficacy on the basis of herbs and spices as antioxidant potentiality [3]

Nyctanthes arbortristis is one of the most useful conventional plants in India. The various parts of plant-like fruits, leaves, seeds, flowers, barks and stem have important phytochemicals and have some medicinal importance for treatment and management of different disease states. Phytochemicals such as flavonoids, oleanic acid, carbohydrates,saponins, tannic acid, carotene, lupeol, benzoic acid present in various parts of plant which have significant antiviral, antifungal, antipyretic, antihistamine, anti-malarial, antibacterial, anti-inflammatory, antioxidant activities On the basis of traditionally claim on Nyctanthes arbortristis plants and due to the lack of proper scientific investigation of their potential pharmacological properties, the main aim of this present study has to determine the antioxidant activity of the plant (Nyctanthes arbortristis)by using reducing power (RP), DPPH scavenging methods $[4,5]$.

\section{Scientific classification}

Biological Source: Nyctanthes arbortristis

Family: Oleacea

Kingdom: Plantae

Order: Lamiales
Genus: Nyctanthes

Species: N. arbortristis

Vernacular names: Night-flowering jasmine (English), Harsingar (Hindi), Shefali (Bengali), Sheali (Assamese).

\section{Distribution of the plant}

It is widely distributed in south Himalayan regions and southwards to Godavari. Each and every part of the plant has some medicinal value so that it is commercially available. It grows at sea level up to $1500 \mathrm{~m}$ altitude, within a range of rainfall patterns. Nyctanthes prefers a scheduled and semi-shady place to grow [6].

\section{Materials and methods}

The roots of Nyctanthes arbortristis was collected from the localities in Rangiya, kamrup, Assam during the month of January 2018. N. arbortristis were collected, shade dried, powdered manually and sieve through a no. 60 mesh sieve. About 100 gms of powdered roots are extracted with the solvents (petroleum ether and methanol) in Soxhlet Apparatus and then it was filtered by muslin cloth and evaporated to dryness by using Rotary Evaporator. The percentage yield of the extract was listed below in table 1:

\section{Phytochemical screening of the extract}

Phytochemical screening was carried out for petroleum ether and hydro-alcoholic extract of $N$. arbortristis for the presence of of different phytoconstituents like alkaloid, flavonoid, phenolics, carbohydrate, glycoside and proteins [7].

\section{In vitro antioxidant study}

\section{Reducing power methods (RP)}

The experiment was performed according to the method given by Oyiazu (1986)[8] In this method the desired concentration of the extract (different conc. $10-100 \mu \mathrm{g} / \mathrm{ml}$ ) suspended in distilled water, $2.5 \mathrm{ml}$ of $0.2 \mathrm{M}$-phosphate buffer (pH6.6), and $2.5 \mathrm{ml}$ of $\mathrm{K}_{3} \mathrm{Fe}(\mathrm{CN})_{6}$ $(1 \% \mathrm{w} / \mathrm{v})$ were added. The mixture was incubated at $50{ }^{\circ} \mathrm{C}$ for 20 min. followed by addition of $2.5 \mathrm{ml}$ of TCA $(10 \% \mathrm{w} / \mathrm{v})$. The mixture was centrifuged at $3000 \mathrm{rpm}$ for $10 \mathrm{~min}$. The upper layer of the solution $(2.5 \mathrm{ml})$ was mixed with distilled water $(2.5 \mathrm{ml})$ and $0.5 \mathrm{ml}$ 
Table 1: Percentage yield of various extracts

\begin{tabular}{ll}
\hline Extract & \% yield \\
\hline Petroleum ether & 6.3 \\
methanol & 8.9 \\
\hline
\end{tabular}

Free radical scavenging activity measured by 1,1-diphenyl-2picryl-hydrazil (DPPH)

The experiment was performed according to the method given by Blois [9]. $0.1 \mathrm{mM}$ solution of DPPH. was dissolved in ethanol to be prepared. $1 \mathrm{ml}$ of this solution was added to $3 \mathrm{ml}$ of each extract solution in water at different concentrations $(4-500 \mu \mathrm{g} / \mathrm{ml})$

The mixture was shaken vigorously and allowed to stand at room temperature for $30 \mathrm{~min}$.

Then the absorbance was measured at $517 \mathrm{~nm}$ using a UV-Vis spectrophotometer.

Lower absorbance values of the reaction mixture indicated higher free radical scavenging

Activity by using Kaempferol as standard [10].

DPPH scavenging effect $(\%)=[(\mathrm{Ao}-\mathrm{A} 1 / \mathrm{Ao}) \times 100]$

Where,

Ao was the absorbance of the control reaction

A1 was the absorbance in the presence of the sample at various concentrations.

\section{Thiobarbituric acid method (TBA)}

The experiment was done according to the method given by Chang et. al [11]. Here the same samples were used those were prepared for FTC method. To desired sample solution, $1.0 \mathrm{ml}$ of $20 \%$ aqueous trichloroacetic acid (TCA) and $2.0 \mathrm{ml}$ of aqueous thiobarbituric acid (TBA) solution were added. The mixture was placed in a boiling water bath and kept for $10 \mathrm{~min}$. Then we have to cool the reaction mixture. After cooling, it was then centrifuged at $3000 \mathrm{rpm}$ for $20 \mathrm{~min}$. Absorbance of the supernatant layer was measured at $532 \mathrm{~nm}$ [12]. Antioxidant activity was recorded based on the absorbance of the final day of the FTC assay. Both methods
(FTC and TBA) were used to describe antioxidant activity by percentage inhibition:

$$
\% \text { inhibition }=\frac{\text { Absorbance of control }- \text { Absorbance of sample }}{\text { Absorbance of control }} \times 100
$$

\section{RESULTS AND DISCUSSION}

\section{Preliminary phytochemical screening}

Pet. Ether and Hydroalcholic extract of $N$. arbortristis roots showed the presence of phenolic, steroids, flavonoids and glycosides (table 2).

\section{In vitro antioxidant effect of Kaempferol, RP, TBA and DPPH} scavenging determination of $N$. arbortristis roots

In the current investigation, it has been found that the Pet. Ether and Hydro alcoholic extracts showed potent antioxidant activity by reducing power, as the concentration of the extracts increased, the absorbance was also increased correspondingly. But the Hydroalcoholic extracts showed more potent activity than the other extracts, as compared with standard substances (Kaempferol) (table 1). The lipid peroxidation of Pet. Ether, Hydroalcoholic extracts and Kaempferol was found to be $29.25,32.12,33.05$ respectively (table 3 ). The in vitro free radical scavenging activity of $N$. arbortristis by Thiobarbituric Acid Method showed the potent percentage inhibition in case of hydroalcoholic extracts as compared to the other extracts. The in vitro free radical scavenging of Pet. Ether, Hydro-alcoholic extract and Kaempferol was found to be 33.05, 8.23, 30.31 respectively (table 2). The free radical scavenging by DPPH method also showed potent result at higher doses for hydroalcoholic extract. From the above findings, it can be concluded that the plant $N$. arbortristis showed the strong antioxidant property. The $\mathrm{IC}_{50}$ value showed good results for hydroalcoholic extracts of $N$. arbortristis in reducing power, TBA and DPPH methods $(5.93,6.16$ and 14.81 respectively). The results for $\mathrm{IC}_{50}$ values for the standard Kaempferol was found to be 2.48 for the above three methods (table 4). The graphical representation of the above-mentioned activities for the various extracts are given in fig. 1, 2, 3 and 4 respectively.

Table 2: Results of preliminary phytochemical screening

\begin{tabular}{|c|c|c|}
\hline Chemical test & Pet. ether & Hydroalcoholic \\
\hline Alkaloid & -ve & -ve \\
\hline Tannins & + ve & $+\mathrm{ve}$ \\
\hline Saponins & + ve & + ve \\
\hline Glycoside & $+\mathrm{ve}$ & +ve \\
\hline Carbohydrates & -ve & -ve \\
\hline Flavonoids & + ve & + ve \\
\hline Proteins and amino acid & $+\mathrm{ve}$ & + ve \\
\hline Phenolics & $+\mathrm{ve}$ & +ve \\
\hline
\end{tabular}

${ }^{*}(+\mathrm{ve})$ and $(-\mathrm{ve})$ symbol indicates the presence and absence of respective plant constituents.

Table 1: In vitro Antioxidant activity of Kaempferol (Stand.), Pet. Ether, Hydro-alcoholic extract of $N$. arbortristis by RP method

\section{* Reducing the power method}

\begin{tabular}{|c|c|c|c|c|c|c|c|}
\hline S. No. & Extracts & Activity & $20 \mu \mathrm{g} / \mathrm{ml}$ & $40 \mu \mathrm{g} / \mathrm{ml}$ & $60 \mu \mathrm{g} / \mathrm{ml}$ & $80 \mu \mathrm{g} / \mathrm{ml}$ & $100 \mu \mathrm{g} / \mathrm{ml}$ \\
\hline 01 & Kaempferol(Stnd.) & & $33.05 \pm 0.001$ & $45.57 \pm 0.002$ & $57.02 \pm 0.001$ & $67.30 \pm 0.05$ & $73.87 \pm 0.01$ \\
\hline 02 & Pet. Ether Extract & Reducing & $12.44 \pm 0.020$ & $21.10 \pm 0.018$ & $28.02 \pm 0.022$ & $35.15 \pm 0.012$ & $43.02 \pm 0.039$ \\
\hline 03 & Hydro alcholic Extract & Power & $17.47 \pm 0.019$ & $26.34 \pm 0.020$ & $34.13 \pm 0.025$ & $46.36 \pm 0.010$ & $57.12 \pm 0.030$ \\
\hline
\end{tabular}




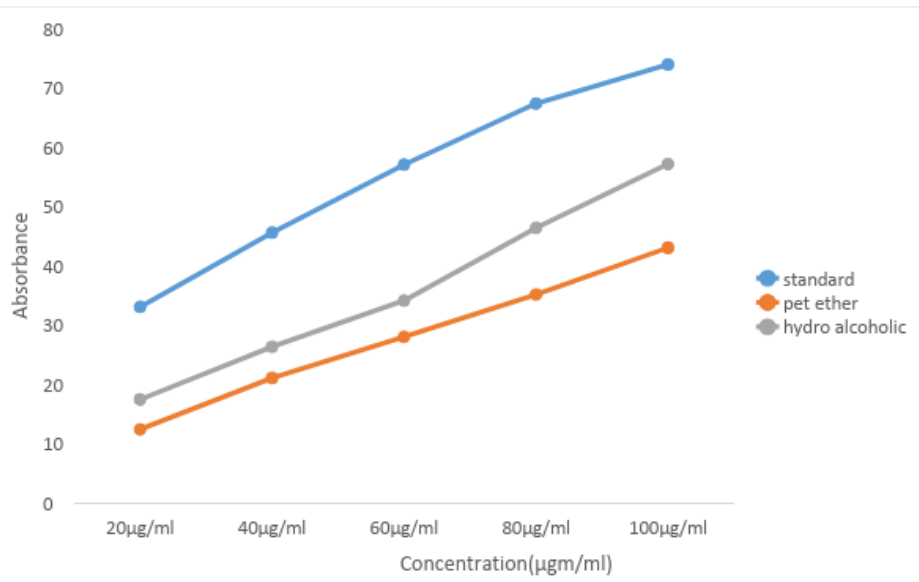

Fig. 1: Reducing power activity of different extracts of $N$. arbortristis

Table 2: In vitro antioxidant activity of Kaempferol (Stand.), Pet. Ether, Hydro-alcoholic extract of $N$. arbortristis by DPPH scavenging method

* DPPH assay

\begin{tabular}{|c|c|c|c|c|c|c|c|}
\hline S. No. & Extracts & Activity & $20 \mu \mathrm{g} / \mathrm{ml}$ & $40 \mu \mathrm{g} / \mathrm{ml}$ & $60 \mu \mathrm{g} / \mathrm{ml}$ & $80 \mu \mathrm{g} / \mathrm{ml}$ & $100 \mu \mathrm{g} / \mathrm{ml}$ \\
\hline 01 & Kaempferol(Stnd.) & & $33.05 \pm 0.001$ & $45.57 \pm 0.002$ & $57.02 \pm 0.001$ & $67.30 \pm 0.05$ & $73.87 \pm 0.01$ \\
\hline 02 & Pet. Ether Extract & DPPH & $08.23 \pm 0.12$ & $14.49 \pm 0.012$ & $15.06 \pm 0.003$ & $18.01 \pm 0.032$ & $21.12 \pm 0.43$ \\
\hline 03 & Hydro alcholic Extract & & $30.31 \pm 0.32$ & $35.47 \pm 0.017$ & $42.06 \pm 0.014$ & $47.51 \pm 0.032$ & $54.32 \pm 0.43$ \\
\hline
\end{tabular}

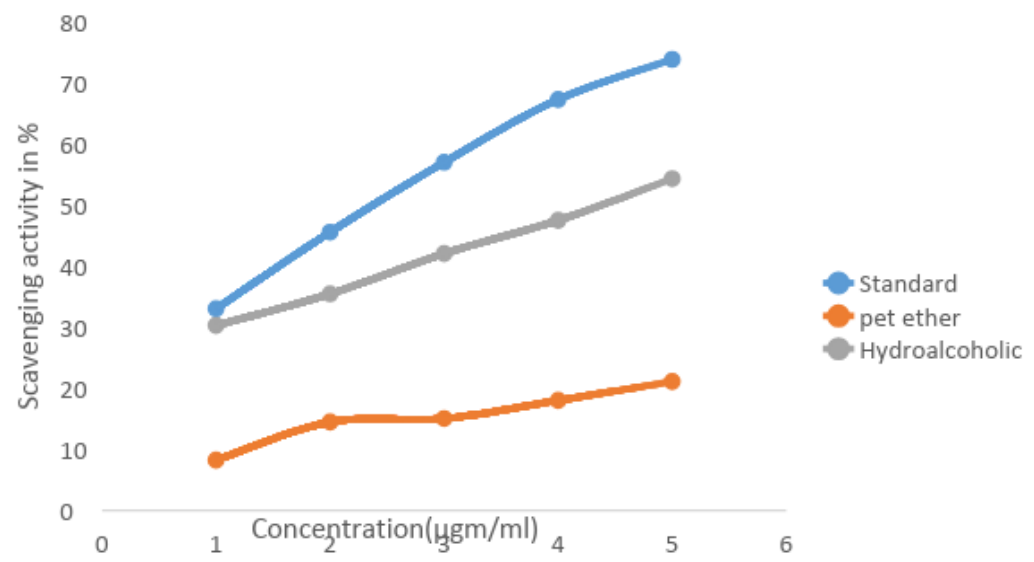

Fig. 2: DPPH scavenging activity of (\% inhibition) of $N$. arbortristis

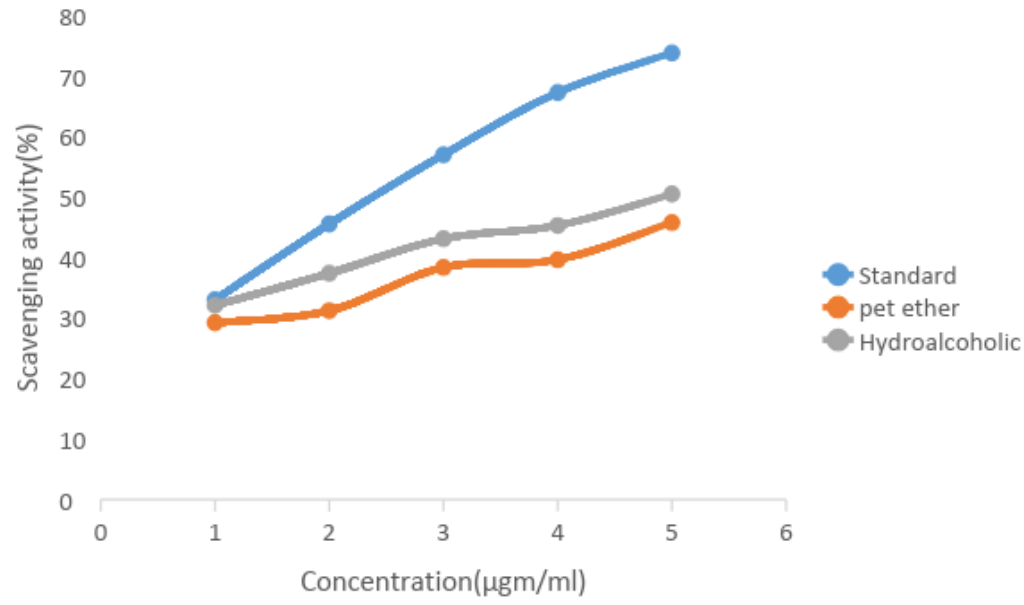

Fig. 3: TBA scavenging power activity (\% inhibition) of $N$. arbortristis 
Table 3: In vitro antioxidant activity of Kaempferol (Stand.), Pet. Ether, Hydro-alcoholic extract of $\boldsymbol{N}$. arbortristis by TBA scavenging method

* TBA method

\begin{tabular}{|c|c|c|c|c|c|c|c|}
\hline S. No. & Extracts & Activity & $20 \mu \mathrm{g} / \mathrm{ml}$ & $40 \mu \mathrm{g} / \mathrm{ml}$ & $60 \mu \mathrm{g} / \mathrm{ml}$ & $80 \mu \mathrm{g} / \mathrm{ml}$ & $100 \mu \mathrm{g} / \mathrm{ml}$ \\
\hline 01 & Kaempferol(Stnd.) & & $33.05 \pm 0.001$ & $45.57 \pm 0.002$ & $57.02 \pm 0.001$ & $67.30 \pm 0.05$ & $73.87 \pm 0.01$ \\
\hline 02 & Pet. Ether Extract & TBA & $29.25 \pm 0.011$ & $31.24 \pm 0.002$ & $38.40 \pm 0.101$ & $39.67 \pm 0.04$ & $45.82 \pm 0.011$ \\
\hline 03 & Hydro alcholic Extract & & $32.12 \pm 0.101$ & $37.43 \pm 0.001$ & $43.14 \pm 0.005$ & $45.34 \pm 0.05$ & $50.54 \pm 0.02$ \\
\hline
\end{tabular}

Table 4: IC 50 value from reducing power, DPPH, TBA Scavenging activity of roots of $N$. arbortristis

\begin{tabular}{|c|c|c|c|}
\hline S. No. & Activity & Extract & IC50 \\
\hline \multirow[t]{3}{*}{01} & Reducing Power & Standard & 2.48 \\
\hline & & Pet. Ether & 4.38 \\
\hline & & Hydroalcholic & 5.93 \\
\hline \multirow[t]{3}{*}{02} & DPPH & Standard & 2.48 \\
\hline & & Pet. Ether & 4.34 \\
\hline & & Hydroalcholic & 14.81 \\
\hline \multirow[t]{3}{*}{03} & TBA & Standard & 2.48 \\
\hline & & Pet. Ether & 4.85 \\
\hline & & Hydroalcholic & 6.16 \\
\hline
\end{tabular}

\section{AUTHORS CONTRIBUTIONS}

All the author have contributed equally

\section{CONFLICT OF INTERESTS}

There was no conflict of interest

\section{REFERENCES}

1. Santosh J, Manojkumar P. A review on nyctanthes arbortristislinn. Rejuvenating drugs. Int J Pharm Pharm Sci 2016;1:54-62.

2. Morel I, Lescoat G, Cogrel P, Sergent O, Pasdeloup N, Cillard P, et al. Antioxidant and iron-chelating activities of flavonoids cetechin, quercetin and diosmetin on iron-loaded rathepatocyte cultured. Biochem Phamacol 1993;45:13-9.

3. Solange IM, Lina FB, Silvia M, Jose AT. Extraction of antioxidant phenolic compounds from spent coffee grounds. Sep Purif Technol 2011;83:173-9.

4. Ondrejovic M, Kraic F, Benkovikiva H, Silhar H. Optimisation of antioxidant extraction from lemon balm (Melissa officinalis). Czech J Food Sci 2012;30:385-93.

5. Ashwini K, Beenu R, Tyagi V. Systemic review on anti-sciatica plant (Night Jasmine). Int J Curr Microbiol Appl Sci 2017;6:1018-35.
6. Divya P, Sheetal P. Phytochemical analysis of leave extracts of nyctanthesarbortristis. J Environ Sci Toxicol Food Technol 2015;1:39-42.

7. Ashwini K, Beenu R, Tyagi V. Systemic review on anti-sciatica plant (Night Jasmine). Int J Curr Microbiol Appl Sci 2017;6:1018-35.

8. Divya P, Sheetal P. Phytochemical analysis of leave extracts of nyctanthesarbortristis. J Environ Sci Toxicol Food Technol 2015;1:39-42.

9. Oyaizu M. Studies on products of browning reactions: antioxidative activities of products of browning reaction prepared from glucosamine. Jpn J Nutr 1986;44:307-15.

10. Hanane E, Nadaya L, Katim A, Yahya C, Abdellah F, Brahim B, et al. Antioxidant activity, phytochemical screening, and total phenolic content of extracts from three genders of carob tree barks growing in Morocco. Arabian J Chem 2011;2:321-4.

11. Chang ST, Wu JH, Wang SY, Kang PL, Yang NS, Shyur LF. Antioxidant activity of extracts from Acacia confusa bark and heartwood. J Agric Food Chem 2001;49:3420-4.

12. Ramazan A, Mehmet C, Ensari F. Protective effects of vitamin E, selenium and allopurinol against stress-induced ulcer formation in rats. Turk J Med Sci 2001;31:199-203. 